ZAPISKi HistoryczNe t. 85, 2020, z. 4, s. 5-24

ISSN 0044-1791

http://dx.doi.org/10.15762/ZH.2020.33

JERZY EISLER*

(iD) https://orcid.org/0000-0003-4708-7548

\author{
December 1970 - Half a Century Later: \\ Current State of Research and New Perspectives
}

\begin{abstract}
What is commonly referred to in Poland as 'December 1970' was one of the most important and most tragic moments in the history of this country after the Second World War. Then, a violent suppression of workers' revolts in several Polish cities on the Baltic coast, by the Citizens' Militia and the army, and the subsequent changes in the leadership of the Polish United Workers' Party took place. After fourteen years in power, the First Secretary of the Central Committee, Władysław Gomułka, was replaced by the former member of the Politburo and also the First Secretary of the Voivodship Committee in Katowice, Edward Gierek. The military operations on the Polish coast, alongside the Citizens' Militia, involved some 27,000 soldiers and 550 tanks, 750 armoured carriers and 2,100 cars. Also, 108 aircraft and helicopters, as well as 40 vessels of the Polish Navy were deployed. Apart from the period of martial law (1981-1983), never during peacetime has the Polish Army been put on standby on such a scale and used to such an extent to pacify the society. According to official data, a total of 45 people were killed and 1,165 wounded on the Baltic coast. Although over 80 books and brochures have already been published on 'December 1970', we still do not know the answers to all the questions. The role played by the Soviet authorities at that time has been researched the least. However, without free access to the post-Soviet archives stored in Russia, which seems hardly possible in the near future, it will be difficult to make new findings on this issue.
\end{abstract}

Keywords: Gdańsk; Gdynia; Szczecin; Edward Gierek; Władysław Gomułka; December 1970; workers' protests; street demonstrations; history of communism; history of historiography

\footnotetext{
* Institute of History, Polish Academy of Sciences; the Branch of the Institute of National Remembrance in Warsaw,

@ jerzy.eisler@ipn.gov.pl
}

Received 13.07.2020; Received in revised form 17.10.2020; Accepted 10.11.2020 


\section{PRELIMINARY REMARKS}

December 2020 marks the fiftieth anniversary of one of the most important and, at the same time, most tragic moments in the history of Poland after the Second World War. During events commonly referred to in Poland as 'December 1970', workers' revolts that took place in several Polish cities located on the Baltic coast were suppressed, in a bloody and violent way, by the Citizens' Militia and the army. This resulted in, among other things, changes in the leadership of the Polish United Workers' Party (Polish Polska Zjednoczona Partia Robotnicza, hereafter abbreviated as PZPR). After fourteen years in office, the First Secretary of the Central Committee (Polish Komitet Centralny) of the party, Władysław Gomułka, was replaced by the former member of the Politburo and at the same time the First Secretary of the Voivodship Committee (Polish Komitet Wojewódzki) in Katowice, Edward Gierek.

It is essential that foreign readers of this text be given a few additional explanations at the very beginning. First of all, Poland under communist rule developed a custom of using names of months (written in capital letters, contrary to the principles of Polish spelling) for cyclical events (every few or more years) that caused deep political turmoil and social upheaval. This distinctive 'Polish Calendar' consists of: June and October 1956, March 1968, December 1970, to which this article is dedicated, June 1976, August 1980, and another December 1981, when the authorities imposed martial law across the entire Polish state. The significance of these symbolic months cannot be overestimated for the modern history of Poland"

It must be noted, that in this way the successive social upheavals shaped oppositional groups that were independent from the authorities, as the names of the months were associated with enormous emotions and sometimes even martyrdom. They symbolised a struggle for subjectivity that significant part of Polish society carried on against the dictatorial power imposed on it from the outside. However, these names are an element of political, and in a way 'magical', language, because they blur rather than clarify anything, and in no way attempt to characterise the events that they represent. Irrespective of all doubts which may be raised by the use of the names of the months, it should also be pointed out that they are all, to a large extent, quite arbitrary, as in practice, the direct and indirect causes and consequences of each of those crises always went beyond the month they are associated with.

Until the political changes in Poland in 1989 were initiated, the government representatives and the so-called 'party scholars' were much less eager

${ }^{1}$ A small-sized book which I have devoted to this issue summarises my over twenty-fiveyear research on the subject, see Jerzy EIsLER, „Polskie miesiace” czyli kryzys(y) w PRL, Warszawa 2008. See also the English version: idem, The "Polish Months": Communist-Ruled Poland in Crisis, trans. Jerzy GiebuŁtowski, Warsaw 2019. 
to refer to political crises and social upheavals with the names of months than independent researchers and the participants of protests. The words that were used more frequently included: 'breakthroughs', 'turns', 'events' and 'accidents', because all these terms were supposed to undermine the impact of these crises and, above all, conceal the bloodshed that they brought about. Therefore, the official publications for many years made use of euphemisms to refer to them, if they were even mentioned at all. For example, terms such as 'Poznań accidents' (of June 1956, Polish wypadki poznańskie) and 'December events' (of 1970, Polish wydarzenia grudniowe) were used. They were intended to trivialise the real nature of social protests and portray them as mere 'accidents' or 'events' that in fact were nothing worthy of attention.

It is interesting that this gimmick designed by social engineering proved to be so successful and these euphemisms were not only used by party propagandists and pseudo-scholars, but also entered permanently into the language of public discourse in Poland. Even with regard to the gravestones of some people killed in 1970, families had to agree, under pressure from the authorities, to an inscription saying that their loved ones had died in 'December accidents', as if it were some sort of car accident. One may have an accident, for example, while skiing or working in a factory, but we cannot use this term to describe a military operation involving thousands of soldiers equipped with heavy gear, combined with shooting people, and resulting in dozens of deaths and hundreds of the wounded.

The same remains true for the second term, that is, 'events'. An event can be an interesting theatre premiere, an international sports championship, a relevant scholarly conference and an important political visit, but in no way one can use it to describe setting fire to the Voivodship Committee of the PZPR buildings or shooting people. Both of these euphemisms imposed by the state propaganda and, unfortunately, still relatively often used today, were aimed at concealing the real nature of the December tragedy. It must not be forgotten that there are obviously other terms used in publications to describe the wave of strikes, street demonstrations and violent clashes with the Citizens' Militia and the army, such as 'revolution', 'insurrection', 'social uprising', 'revolt', 'incidents' and 'riots'. All these are more appropriate than the unfortunate 'events' and 'accidents'. The contemporary terms most frequently used by the officials of the Ministry of Internal Affairs in December 1970 were 'disturbances' and 'rebellion', and the demonstrators, even in some official documents produced at the time, were referred to as 'rebels'.

For the sake of scholarly reliability, it is appropriate to recall yet another name used by the leaders of the PZPR at that time, especially First Secretary of the Central Committee Władysław Gomułka, namely 'counter-revolution' On Thursday, 17 December 1970, the most dramatic and bloody day of the 
workers' protest, during a telephone conversation Gomułka convinced the General Secretary of the Communist Party of the Soviet Union Leonid Brezhnev, that a counter-revolution was taking place in Poland. According to Soviet politicians who were listening to the conversation, Gomułka authoritatively stated that these are 'organised incidents, brawls against our policy. Their aim is to cause discontent among workers. They are counter-revolutionary in nature. They are inspired by the ringleaders. The authorities do not deal with workers, but with counter-revolution. Even ordinary criminals joined in'. Gomułka insisted that it was a 'provocation against the authorities'. He also assured Brezhnev that the party and state leadership was doing its utmost to ensure that this 'would not spill across the country'. When Brezhnev tentatively asked: 'Was it necessary to deploy the army and give orders to use firearms?', Gomułka exclaimed: 'Alas, we are dealing with a counter-revolution, Comrade Brezhnev! [...] Do you know what Lenin said about dealing with counter-revolution? You know for sure, it must be dealt with by force, otherwise it will destroy us'. When the General Secretary remarked that the people in the streets were workers, the members of the 'working class', Gomulka retorted that this was false information. 'It is not the working class - he roared - [...] it is a counter-revolution and we will deal with it properly. Remember Kronstadt! Was it not a counter-revolution? And what did Lenin do with it? He crushed the Kronstadt mutiny with force.'Brezhnev did not give in: 'We have information that there are thousands of people on the streets of Gdańsk and other cities, tens of thousands, and perhaps even more people. Are all of them counter-revolutionaries? After all, they are working people, workers. Are you shooting at workers? At the working class? [...] If you shoot at workers, then who will you build socialism with, Comrade Gomułka?. Gomułka remained unconvinced: 'There are no normal workers there, normal workers do not take up arms against people's government, let me tell you again, it is a counter-revolution'2.

2 '[...] to zajścia zorganizowane, burdy przeciwko naszej polityce. Ich celem jest wywołanie niezadowolenia robotniczego. Mają one charakter kontrrewolucyjny. Toczą się pod dyktando prowodyrów. Władza nie ma do czynienia z robotnikami, lecz z kontrrewolucją. Dołączyły się do tego elementy kryminalne'; 'Czy trzeba było wprowadzać wojsko i wydawać rozkazy o użyciu broni palnej?'; 'Toż to kontrrewolucja, towarzyszu Breżniew! [...] A wiecie, co Lenin mówił o rozprawianiu się z kontrrewolucją? Na pewno wiecie - trzeba się z nią rozprawiać siłą, bo inaczej ona nas zniszczy'; 'To żadna klasa robotnicza. [...] to kontrrewolucja i my się z nią należycie rozprawimy. Przypomnijcie sobie Kronsztad. Czy nie była to kontrrewolucja? I co z nią zrobił Lenin? Siłą zdusił bunt kronsztadzki'; 'Mamy informacje, że na ulicach Gdańska i innych miast są tysiące ludzi, dziesiątki tysięcy, a może i więcej ludzi. Co, wszyscy są kontrrewolucjonistami? Przecież to ludzie pracy, robotnicy. Strzelacie do robotników? Do klasy robotniczej? [...] Jeśli strzelacie do robotników, to z kim będziecie budować socjalizm, towarzyszu Gomukka?'; 'Tam nie ma normalnych robotników, normalni robotnicy nie podnoszą ręki na władzę ludową, powtarzam wam, to kontrrewolucja. All quotes in the article have been translated into English by Tomasz Leszczuk. There are three accounts of this conversation between Brezhnev 
The course of this conversation, if the head of the Polish Sector at the Central Committee of the Communist Party of the Soviet Union, Piotr Kostikow, accurately recreated it, is simply frightening. Gomułka manifests his doctrinaire approach and he seems to have been overwhelmed by the way the events developed. He perceived the social revolt only in terms of a counter-revolution. It seems that he did not understand the essence of the protest, nor did he know which political means could help him solve such a crisis. It is hard to believe that the same man fourteen years earlier had identified the reasons for the workers' rebellion in Poznań so aptly. In contrast to the terms 'events' and 'accidents', which reduced the social significance of the protests, the term 'counterrevolution' was perhaps intended to overstate the gravity of the situation.

Interestingly, it was not only Gomułka that had a tendency to exaggerate the December tragedy. His successor, Edward Gierek, during a conversation with the leaders of the German Democratic Republic, stated in September 1971 that over the past nine months, 'the situation in the country, which was on the verge of civil war in December, had been brought under control's. It is difficult to say whether Gierek really believed that Poland was facing the threat of civil war in December 1970, or whether, for some reason, he purposely exaggerated it. Regardless of the reasons, he was not the only one who had a tendency to exaggerate the scale of the crisis when talking to the representatives of other socialist and communist parties. During the conversation held on 27 April 1971 between the new Secretary of Central Committee of the PZPR, Stanisław Kania, and the new Soviet ambassador to Poland, Stanisław Piłotowicz, the former 'mentioned several times the difficult and dangerous situation that took place in the country, especially before the $7^{\text {th }}$ Plenary Session of the Central Committee of the PZPR. He said that at that time a wrong decision to use firearms against the working class was made. [...] If measures had not been taken to change the leadership and resolve the conflict politically rather than by force, as Kania stressed, the consequences could be far more serious's

and Gomułka, see Piotr Kostikow, Bohdan Rolıński, Widziane z Kremla. Moskwa-Warszawa. Gra o Polskę, Warszawa 1992, pp. 140-142. Cf. Jerzy EIsler, Stanisław Trepczyński, Grudzień '70 wewnatrz „Białego Domu”, Warszawa 1991, pp. 95-99; Tajne dokumenty Biura Politycznego. Grudzień 1970, opr. Paweł Domański, Londyn 1991 (further cit. Tajne dokumenty), pp. $422-423$.

3 '[...] opanować sytuację w kraju, która w grudniu ub. roku zawierała groźbę wojny domowej; a memo from the meeting with the representatives of the political leadership of the German Democratic Republic from 18-20 September 1971. Special thanks to Prof. Marcin Zaremba for making this document available.

4 '[...] kilkakrotnie wspominał o trudnej i niebezpiecznej sytuacji, jaka miała miejsce w kraju, zwłaszcza przed VII Plenum KC PZPR. Mówił, że podjęto wówczas błędną decyzję o użyciu broni wobec klasy robotniczej. [...] Gdyby nie podjęto środków polegających na zmianie kierownictwa oraz rozwiązaniu konfliktu na drodze politycznej, a nie siłowej - jak podkreślił 
It may be puzzling that the social circles close to the state authorities eagerly accentuated the reformist (according to the views of the members of the ruling party) and intra-systemic (i.e. not challenging the foundations of the political system, as opposed to anti-systemic) nature of the 'December events'. Some of the supporters of this option were often willing, and sometimes are still willing, to defend at all costs the achievements of the period of the communist rule in Poland. They are ready to admit, though unwillingly, that the Stalinist Era in the post-war history of Poland was sinister, but the years that followed should not be judged too harshly, even though it was then that the streets of Polish cities became the scene for violent social protests, and even bloodshed.

For the sake of balance, it should be mentioned that for many people from certain right-wing circles, the entire period when Poland was under communist rule was in practice one big political and social crisis. At the same time, the representatives of this political allegiance seldom pay attention to the differences between successive stages of Poland's post-war history, and often treat the entire communist period as a uniform whole. It is clear that both of these attitudes, which I deliberately sharpened, do not contribute to deepening the understanding of these historical event and answering the many relevant questions. Perhaps the fiftieth anniversary of December 1970 will be a good pretext for this kind of consideration.

\section{THE WEEK THAT SHOOK POLAND}

How to classify a particular social revolt certainly depends on its direct and indirect causes. Was the underlying reason only economic? Or perhaps, over time the demands of a social and, ultimately, political nature appeared alongside economic slogans? In the latter case, however, it should be remembered that in the communist political system, the concept of 'political demands' was treated very broadly. In exceptional cases, in fact, it was possible to define every slogan and action as 'politically hostile'.

In December 1970, the direct cause of the workers' protest was the drastic increase in prices for many basic commodities, and especially food, introduced 11 days before Christmas, when in Poland it was part of tradition to buy more and better (which meant more expensive) food, even in poorer families. At this

Kania - mogłoby to mieć bardzo poważne skutki; Архив внешней политики Российской Федерации [Arkhiv vneshney politiki Rossiyskoy Federatsii], archival unit no. 122, catalogue no. 56, folder no. 419, archival reference no. 7, pp. 3-4. Many thanks to Dr. Vadim V. Volobuyev for making the document available. For a valuable monograph by this author, see Вадим В. Волоьуев, Польша - 1970: Репетиция «Солидарности», Москва-Санкт-Петербург 2012 [Vadim V. Volobuyev, Pol'sha - 1970: Repetitsiya «Solidarnosti», Moskva-Sankt-Peterburg 2012]. 
point, however, it also seems justified to ask whether such a violent wave of social protests would still occur if the political, social and economic situation in Poland at that time was at least satisfactory? It seems that in December 1970 the authorities did not take this seriously, although at the same time preparations were made in the army, the Citizens' Militia and the Security Service to deal with possible social protests.

Perhaps the vigilance of the party and state authorities, and especially of Gomułka himself, was dulled to some extent by the enormous success achieved a few days earlier on the international level. That is, of course, the signing of the Treaty of Warsaw that normalised the mutual relations between the Polish People's Republic and the Federal Republic of Germany on 7 December 1970, in the Column Hall of the Council of Ministers building at Krakowskie Przedmieście in Warsaw (the same one where the Warsaw Pact was established in 1955, and where the talks of the Round Table were held in 1989). The document was signed by the heads of both governments, Willy Brandt and Józef Cyrankiewicz, and the ministers of foreign affairs Stefan Jędrychowski and Walter Scheel. The ceremony was held under the patronage of Gomułka, for whom it was certainly one of the most important and happiest days in his entire political career. He had the right to consider the signing of the treaty with Germany as his great personal success. He was probably convinced that most Poles had a similar perception of this historic event. Under the treaty, 25 years after the Second World War ended, Germany officially recognised the Polish western border running along the rivers Oder and Lusatian Neisse. Nevertheless, despite the enormous development of the historical research on December 1970, it is still uncertain whether at any point in the negotiations with Germany the leaders of the PZPR, including Gomułka himself, considered using the treaty as a kind of 'distraction' from or 'compensation' for the planned price increase.

The fact is that the price increase was announced suddenly, on Saturday evening, on 12 December, when shops had already closed throughout the country. However, it is also true that all throughout that day crowds of people had been cramming the shops to buy literally anything that was left in stock, as the rumours about a price increase were heard at least a few hours ahead of the official announcement. On Monday morning, the first strike broke out at Lenin Shipyard in Gdańsk. On the same day in the afternoon, violent street fights took place in the city, although on that day the law enforcers did not yet use firearms, so there were no fatalities.

In the following days, the wave of protests spilled across the country, although luckily they did not take such a tragic turn everywhere as they did in the Baltic coast. Nevertheless, demonstrations and clashes with law enforcers on the streets were also observed in the inland areas, for example in Kraków, Białystok, Słupsk and Wałbrzych. In several other cities, shorter or longer 
strikes took place. In total, from 14 to 19 December 1970, tens of thousands of people in several cities took more or less active part in street fights. They used, among other things, stones, bottles with petrol and other flammable liquids, metal nuts, screws, iron crowbars, and occasionally also firearms. The source of the firearms was unknown. In official reports, which were not known to the public, it was suggested that these weapons had previously been taken away by demonstrators from the Citizens' Militia. However, one can look at it from a different angle. The fact that the police officers were shot at from the crowd did not necessarily mean that it was the protesters who were shooting. They might have been shots fired deliberately or by mistake by other officers. In communist Poland, access to firearms was difficult for civilians. However, the representatives of the uniformed services did not have such problems. Such considerations, however, may lead us towards various conspiracy theories, which have their staunch supporters, but are usually not recognised by professional historians. The latter prefer to rely on the so-called hard evidence rather than on speculation. It can only be added that some of the shipyard workers were wearing helmets and some of the street fight participants were wearing protective masks. The clashes were often very violent, and the value of the material damage caused by the destruction exceeded 400,000,000 zlotys. Nineteen public buildings were set on fire and completely or partially destroyed, including the Voivodship Committee of the PZPR buildings in Gdańsk and Szczecin.

In December 1970, a total of 27,000 soldiers and 550 tanks, 750 armoured carriers and 2,100 cars took part in military operations on the Baltic coast. Moreover, 108 aircraft and helicopters were involved, as well as 40 vessels of the Polish Navy. 'Together with the military forces that were moved to designated areas but not used for action, as well as with groups put at disposal of the local authorities for the internal protection of facilities in a large area of the country, roughly 61,000 soldiers, 1,700 tanks, 1,750 armoured carriers and

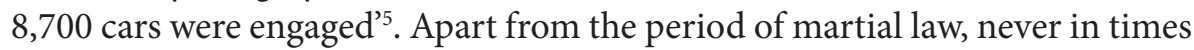
of peace has the Polish Army been put on standby on such a scale and used to such an extent to maintain law and order. One must also add over 10,000 militiamen, officers from the Volunteer Reserve of the Citizens' Militia, the Security Service, the prison guard or even the fire brigade, who were mobilised and deployed. On 17 December alone, a total of 4,227 militiamen and 540 Volunteer Reservists took part in the pacification of street protests in several cities. A total of approximately 79,000 rounds of ammunition containing chemical

${ }^{5}$ 'Razem z siłami, które zostały przesunięte w wyznaczone rejony ale nie użyte do akcji, jak również łącznie z grupami skierowanymi do dyspozycji miejscowych władz dla wewnętrznej ochrony obiektów na znacznym obszarze kraju - zaangażowano około: 61 tys. żołnierzy, 1700 czołgów, 1750 transporterów opancerzonych i 8700 samochodów’; Tajne dokumenty, p. 85. 
agents were used over six days ${ }^{6}$. According to official data, a total of 45 people were killed and 1,165 wounded on the Polish Baltic coast.

It is clear that this situation was something that goes beyond simple, unambiguous assessments and stereotypes. In fact, I am not at all convinced that all that happened in December 1970 can be described by one word. After all, there were at least several layers to that conflict. There is no doubt that some demonstrators deliberately took part in an economic strike caused by this price increase, which was then followed by a street demonstration. Finally, when violent fighting took place, and especially when shots were fired and the first victims appeared as a result, many of them actively engaged in clashes with law enforcers. There were also those for whom the protest was not only socio-economic from the outset, but also political, anti-communist, anti-government, anti-Soviet, and perhaps even pro-independence, and thus almost immediately became insurrectionary in nature. People of this type often came from families with a strong tradition of being anti-communist, and struggling for freedom and independence of their homeland. However, it is also hard not to notice that among the crowds of thousands of people who were watching the Voivodship Committee of the PZPR buildings burning down in Gdańsk and Szczecin, casual bystanders dominated. It would not be far from the truth to say that very many (maybe even the majority) of these people watched the fires with surprise, disbelief, but also often with satisfaction, or even with joy.

However, at least one more category of those who participated in the demonstrations must not be lost sight of. Namely, common hooligans, people who were simply looking for an opportunity to make trouble and take part in a brawl, all those who always join street demonstrations and then take a very active part in clashes with law enforcers. However, caution and moderation must be exercised here, bearing in mind how the role of these very people was made public in the media at the time. After all, under the rule of real socialism, it was customary on such occasions to speak mainly about hooligans, bandits, thieves, criminals, and so on. Certainly not all the people who were called that indeed deserved it, but it cannot be said that the participation of such people was of marginal importance. If that were true, such a significant proportion of those killed, injured or detained would not already have been convicted of common crimes before.

\section{Current state of Research on December 1970}

December 1970 is one of those topics which was hardly ever officially raised in Poland, that is to say, it was subjected to preventive censorship, until

${ }^{6}$ Grudzień 1970 w dokumentach MSW, opr. Jerzy EIsLER, Warszawa 2000 (further cit. Grudzień 1970 w dokumentach MSW), p. 12. 
the communists were removed from power. It was only from 1990 onwards, mainly on the occasion of round anniversaries, that a large number of books and articles devoted to these issues began to be published. One can observe that a circle of authors, which included around 10 people, who deal with the December 1970 issues and who usually reverted to it more than once, has become increasingly more stable. They are listed here in an alphabetical order: Zbigniew Branach, Piotr Brzeziński, Sławomir Cenckiewicz, Jerzy Eisler, Andrzej Głowacki, Eryk Krasucki, Henryk M. Kula, Wiesława Kwiatkowska, Edward J. Nalepa and Michał Paziewski. These authors, not all of whom are historians by education, have prepared the vast majority of more than 80 books and brochures devoted to the December tragedy that have been published to date. The bibliography of December 1970 prepared by Krzysztof Chalimoniuk (as at the end of November 2010, i.e. before the next wave of anniversary publications) included a total of 315 printed items (wherein various articles were included) and additionally nine sound recordings from the collections of the National Digital Archive in Warsaw 7 .

The poor state of historical knowledge about December 1970 among Polish society, or rather the lack thereof, is not so much a consequence of the scholars' negligence in providing historical studies to the broader public, but rather of the people's failure to read them. With the exception of the Polish Baltic coast, where the memory of the December tragedy remains vivid to this day, the country's interior is usually reminded of December 1970 on the occasion of round anniversaries. At the same time, it is impossible not to notice that, although it might seem that the subject has already been very well researched and it would be difficult to say something new and original about that tragedy, the so-called common knowledge of the subject is extremely superficial and shallow. In Gdańsk and Szczecin I have been confronted with this very question from the participants of the December revolt on several occasions: 'Why are there virtually no books published about this tragedy?. I tried in vain to explain that many scholarly works are written and published, and that several dozen books and brochures have already been published on the subject over the past few years, but I do not think this argument convinced the askers.

It should not be forgotten that in some anti-communist circles false information, rumours of allegedly hundreds of dead demonstrators, militiamen dressing up in military uniforms ${ }^{8}$, burials of fallen demonstrators in mass

${ }^{7}$ Krzysztof Chalimoniuk, Bibliografia Grudnia '70, Rocznik Gdyński, nr 22: 2010, pp. 85-115. It should be remembered that this bibliography contains only texts entirely devoted to December 1970, and not the ones where it appears alongside other events, issues or social phenomena, such as academic textbooks and syntheses of the post-war history of Poland.

${ }^{8}$ Here, the foreign readers of the text need to be provided with an explanation. In communist Poland, while the agencies subordinate to the Ministry of Internal Affairs (mainly the 
graves (in plastic bags), and Soviet soldiers allegedly involved in suppressing the rebellion were widely spread. And the argument often used for dissemination of such unconfirmed revelations was that 'Poles would not be so brutal and cruel'.

For the sake of scholarly reliability, it should also be recalled that the first books and brochures on December 1970 were published outside Poland because of the censorship ${ }^{9}$. Initially, in domestic publishing houses operating in the underground, outside the reach of censorship, the collections of accounts from the participants of workers' protests were published, together with the documents produced by the protesters (e.g. leaflets or lists of strike demands).

The first book on December 1970 officially published in Poland was a work written by Mieczysław F. Rakowski, editor-in-chief of the Polityka weekly in February 1981, before he became Deputy Prime Minister. He had been a member of the Central Committee of the PZPR and a member of parliament. He had extensive contacts in the communist establishment, and a facilitated access to many official documents. He was therefore the first to describe not only the workers' protest, but also, to some extent, the behind-the-scene workings of the political apparatus ${ }^{10}$.

Security Service and the Citizens' Militia) usually did not induce affection or recognition among the Polish society (although they were generally feared), the army continuously was one of those state institutions which enjoyed immense social trust. Respect and admiration for the soldier's uniform remained vivid among numerous social groups and many people took the officer's word of honour seriously. It is therefore hardly surprising that in December 1981 (under martial law), the striking workers were often ready to end their protest and leave the occupied facility, convinced by the officers of the Polish People's Army, but not by the militiamen. As a consequence of this high esteem for the army as an institution, and the lack of respect and appreciation for the Citizens' Militia and the Security Service, there was a widespread conviction that 'their' (i.e. the authorities') militia, and not 'our' (i.e. the society's) army, had been responsible for all brutal actions, iniquities and sometimes even crimes. This was accompanied by a relatively common belief (also in December 1970) that the demonstrators were shot at by militiamen dressed in military uniforms, and not by the soldiers. However, no one has confirmed this so far, but the opposite did take place. In March 1968, for example, there was indeed a documented case of soldiers wearing militia uniforms that were still 'stinking of storage room'. See Jerzy EISLER, Polski rok 1968, Warszawa 2006, pp. 247-248.

${ }^{9}$ For example, Grudzień 1970 r. w Polsce, Toronto 1971; Poznań 1956 - grudzień 1970, [opr. Ewa WacowsKa], Paryż 1971; Rewolta szczecińska i jej znaczenie, opr. Ewa Wacowska, Paryż 1971 (further cit. Rewolta szczecińska i jej znaczenie); Marek TARNIEwsKi [Jakub KARPIŃsKi], Płonie komitet (grudzień 1970 - czerwiec 1976), Paryż 1982. In the 1980s, alongside various brochures containing, above all, accounts by witnesses and participants in the December tragedy, the published books were mainly prepared in Poland under the auspices of the Independent Self-Governing Free Trade Union 'Solidarity', which first operated legally and openly, and later in the underground. See Zygmunt Korybutowicz [Andrzej Friszke], Grudzień 1970, Paryż 1983; Grudzień 1970, Paryż 1986; Małgorzata Szejnert, Tomasz Zalewski, Szczecin. Grudzień - sierpień - grudzień, Londyn 1986.

${ }^{10}$ Mieczysław F. Rakowsкi, Przesilenie grudniowe. Przyczynek do dziejów najnowszych, Warszawa 1981. 
The real breakthrough in research, however, only took place in Poland with the political changes initiated in 1989. They coincided with the twentieth anniversary of December 1970. It was only then that the first books, varying in quality, were officially published, which contained more or less interesting reflections on the struggle over political power among the PZPR leadership, in addition to the description of the workers' rebellion ${ }^{11}$. In the following years a lot of valuable works on December 1970 appeared. First of all, one should mention here a stirring book based mainly on the accounts of witnesses and participants of those events, written by Wiesława Kwiatkowska, whose contribution to the research on the December revolt (especially in Gdynia) simply cannot be overestimated ${ }^{12}$. The real abundance of this type of publications traditionally took place at the next round anniversary in December 2000, when in just a few weeks at least six publications devoted to this issue were published, not to mention a large number of journal articles ${ }^{13}$.

Wiesława Kwiatkowska, together with her daughter Małgorzata Sokołowska, also initiated the publication of the first album including both scholarly texts and illustrations on December 1970. Unfortunately, she was not given the opportunity to complete her work on the volume, as she passed away on 18 June 2006. Some of the texts she wrote for this volume were polished and prepared for publication by Izabella Greczanik-Filipp ${ }^{14}$. Kwiatkowska was also the authoress of the first historical study on the course of events of December 1970 in Elbląg published by the underground press, which for a long time was the only larger text dedicated to this issue. Unfortunately, the first official multi-author volume on December 1970 in Elbląg, in which a slightly

${ }^{11}$ The following titles were published: Zbigniew BRANACH, Grudniowe wdowy czekaja, Wrocław 1990; Andrzej GŁowaCKI, Kryzys polityczny 1970 roku, Warszawa 1990; Tadeusz GóRsKI, Henryk Kula, Gdańsk - Gdynia - Elblag '70. Wydarzenia grudniowe w świetle dokumentów urzędowych, Gdynia 1990; Edward J. NALEPA, Wojsko Polskie w grudniu 1970, Warszawa 1990; Henryk Piecuch, Rozstrzelany grudzień, Warszawa 1990; Barbara SeIdler, Kto kazał strzelać. Grudzień '70, Warszawa 1991.

${ }^{12}$ Wiesława Kwiatкowska, Grudniowa apokalipsa, Gdynia 1993. It was an extended version of the book Grudzień 1970 w Gdyni, opr. Wiesława Kwaśniewska [Wiesława KwiatkowSKA], Warszawa 1986. It was first published as part of the underground series 'Archives of the Solidarity'.

${ }^{13}$ They were in alphabetical order: Tomasz Balbus, Łukasz KamiŃsкi, Grudzień '70 poza Wybrzeżem w dokumentach aparatu władzy, Wrocław 2000; Bogumiła Danowska, Grudzień 1970 na Wybrzeżu Gdańskim. Przyczyny - przebieg - reperkusje, Pelplin 2000; Jerzy EISLER, Grudzień 1970. Geneza, przebieg, konsekwencje, Warszawa 2000; Grudzień 1970 w dokumentach MSW, passim; Henryk M. Kula, Dwa oblicza Grudnia '70. Oficjalne - rzeczywiste, Gdańsk 2000; Wiesława Kwiatrowska, Izabella Greczanik-Filipp, Sq wśród nas, Gdynia 2000.

${ }^{14}$ To nie na darmo... Grudzień '70 w Gdańsku i Gdyni, red. Małgorzata SoкоєowsкA, Pelplin 2006. 
shortened version of her study was reprinted with her consent, was published after her demise ${ }^{15}$.

Since the mid-2000s, research into December 1970, but also into Poland's recent history has been dominated, and partially even monopolised, by the Institute of National Remembrance (Polish Instytut Pamięci Narodowej, hereafter abbreviated as IPN), established in the year 2000, which employs hundreds of historians specialising in the recent history of Poland, has considerable financial resources at its disposal, and owns a publishing house. Since the IPN also has a large archival collection, produced mainly by the communist apparatus responsible for state violence and political repressions, it is not surprising that some of these newer publications on December 1970 are album-like or at least richly illustrated with photographs taken, or sometimes requisitioned, by the officers of the Security Service.

In the following years, album-like publications were supposed to make up a significant percentage of all publications on December 1970. It is also important to note that a lot of attention was paid to Szczecin, which remained overshadowed by the events in Gdańsk and Gdynia, despite the publication of many articles on December 1970 in the city, mainly by the expert on the subject Michał Paziewski. In 2007, the employees of the Branch Office of the IPN in Szczecin, Małgorzata Machałek and Paweł Miedziński, prepared an album consisting of 445 photographs, mostly unknown, and in large part cropped from a documentary film on the strike in Szczecin, which was found in the archival collection of the IPN ${ }^{16}$. The introductory text was prepared by Eryk Krasucki, who dealt with the history of December 1970 in Szczecin more extensively in the following years.

Gdańsk did not want to be left behind. In 2009, a researcher belonging to the local Branch Office of the IPN, Sławomir Cenckiewicz, prepared an album devoted to December 1970 in Gdańsk, consisting of over 300 photographs and scans. As the literature on the subject is very rich, it might seem that it would be extremely difficult to say something new and interesting on this topic. However, Cenckiewicz found a unique way to show the events of that time through the prism of documents and photographs made by the officers of the Security Service ${ }^{17}$.

Also Gdynia, which had the largest death toll in December 1970, has seen an album devoted to the tragedy that took place in the streets of the city. In 2010,

${ }^{15}$ Wiesława Kwiatкowska, Grudzień 1970 w Elblagu, Elbląg 1988. An abridged version of this text was published in Elblag w grudniu 1970 roku, red. Janusz Hochleitner, Elbląg 2006.

${ }^{16}$ Małgorzata Macha£ek, Paweł Miedziński, Zbuntowane miasto. Szczeciński Grudzień '70 - Styczeń '71, Szczecin 2007.

${ }^{17}$ Sławomir Cenckiewicz, Gdański Grudzień '70. Rekonstrukcja - dokumentacja - walka z pamięcią, Gdańsk-Warszawa 2009. 
several consecutive anniversary books on the subject came to light, mainly, although not exclusively, prepared by the IPN, including an album published by three young researchers from the Branch Office of the IPN in Gdańsk ${ }^{18}$. Piotr Brzeziński, Robert Chrzanowski and Anna Nadarzyńska-Piszczewiat decided to take a closer look at the course and the consequences of December 1970 in Gdynia, and thus follow in the footsteps of Wiesława Kwiatkowska. Obviously, on account of the historical records stored at the Branch Office in Gdańsk, they had an incomparably wider access to primary sources than Kwiatkowska. This was especially true of numerous iconographic materials, which allowed them to publish their work in the form of an album. However, the young historians did not limit themselves to iconography. They prepared a substantive text divided into several parts, based on their own analysis of primary sources carried out mainly in the Archives of the Institute of National Remembrance, but also in the State Archives in Gdańsk and the Central Archives of Modern Records in Warsaw. They also made extensive use of the memoirs and collections of accounts, to which they even contributed themselves, as they conducted interviews with witnesses and participants of the described events.

However, in connection with the fortieth anniversary of December 1970, it was Szczecin, which so far had remained in the background of the research, and not the Tricity (consisting of the cities of Gdańsk, Gdynia and Sopot) that became the centre of historians' attention. It is difficult to explain why in terms of collective memory December 1970 for so long had been associated almost exclusively with Gdańsk, to a lesser extent with Gdynia, where the events had taken the bloodiest and most tragic turn, hardly ever with Elbląg, and exceptionally seldom with Szczecin. It comes as a surprise as it was in Szczecin that, on the one hand, the most violent street fights took place, and on the other the protest became the most mature. While the value of material damage in Gdańsk, Gdynia and Elbląg was estimated at a total of 105,000,000 zlotys, it reached 300,000,000 in Szczecin alone. It should also be remembered that it was in Szczecin that the General City Strike Committee (Polish Ogólnomiejski Komitet Strajkowy) was formed, which, at its peak, brought together around 120 factories, and which briefly became the real governing body of the 'Republic of Szczecin' - as the deputy member of the Politburo of the PZPR Jan Szydlak, vividly described the rebellious city. It is also worth remembering that it was in Szczecin in 1970 that the demand for the creation of independent trade unions was raised, whatever this might have meant in the political circumstances of that time.

${ }^{18}$ Piotr Brzeziński, Robert Chrzanowski, Anna NadArzyńska-Piszczewiat, Zbrodnia bez kary. Grudzień 1970 w Gdyni. Przebieg wydarzeń, represje, walka o prawdę, Gdynia 2010. 
However, it seems that, mainly but not exclusively, due to publications prepared by the Branch Office of the IPN in Szczecin, which published four valuable books on the subject, knowledge about the course of the crisis in the winter of 1970/1971 in that city became significantly more widespread among the general public. The multi-author volume published jointly by the University of Szczecin and the Branch Office of the IPN in Szczecin, edited by Maciej Kowalewski, Eryk Krasucki and Paweł Miedziński, certainly contributed to this ${ }^{19}$.

The smallest in terms of page count but valuable in terms of contribution is the multi-author volume edited by Sebastian Ligarski and prepared in the Branch Office of the IPN in Szczecin, which supplements the previously mentioned publication ${ }^{20}$. The source edition prepared by three employees of the Branch Office for Accessing and Archiving Documents of the IPN in Szczecin, that is, Tomasz Błaszak, Magdalena Dźwigała and Tomasz Kenar is completely different. It is a collection of 52 documents, supplemented with a short introduction and footnotes, produced by the local branches of the Security Service, currently stored in the Archives of the Institute of National Remembrance in Szczecin ${ }^{21}$.

The fourth of the books published by the Branch Office in Szczecin at that time was prepared by Eryk Krasucki22, who made the crisis of 1970/1971 one of his main research fields. Apart from a very interesting, substantive introduction, which presents, in a scholarly manner, the origins, background and consequences of the January strike in the Szczecin Shipyard, this volume consists primarily of 250 chronologically arranged documents from various state and private archives. In my opinion, the inclusion of some press articles from local newspapers in the collection was also a good idea. The diversity of the historical records that this fascinating work made easily available to the readers is undoubtedly one of its assets.

In a sense, this book is complemented by a work prepared by one of the most eminent scholars dealing with December 1970, Michał Paziewski, within the framework of the Association of the 'Archives of the Solidarity' (Polish Stowarzyszenie „Archiwum Solidarności”), and published as a part of the publishing series Biblioteka Więzi ${ }^{23}$. It is a completely unique book whose significance

${ }^{19}$ Historia, miasto, pamięć. Grudzień '70 - styczeń '71 (perspektywa szczecińska), red. Maciej Kowalewski, Eryk Krasucki, Paweł Miedziński, Szczecin 2010.

${ }^{20}$ „Intelektualiści polscy milcza zupełnie”. Grudzień 1970 - styczeń 1971 w Szczecinie, red. Sebastian Ligarski, Szczecin 2010.

${ }^{21}$ Szczeciński Grudzień '70 w dokumentach Służby Bezpieczeństwa, red. Tomasz BŁAszaK, Magdalena DźwigaŁa, Tomasz Kenar, Szczecin 2010.

${ }^{22}$ Eryk KRAsucki, Szczecińskie społeczeństwo i władza w styczniu i lutym 1971 r. Obraz źródłowy, Szczecin 2010.

${ }^{23}$ Michał PazIEwski, Debata robotników z Gierkiem. Szczecin 1971, Warszawa 2010. 
goes far beyond the history of December 1970, and encompasses the history of Poland after the Second World War in general. It is the publication of a stenographic record of the meeting between the First Secretary of the Central Committee of the PZPR, Edward Gierek, and Prime Minister Piotr Jaroszewicz, alongside Wojciech Jaruzelski, Franciszek Szlachcic, Kazimierz Barcikowski and other party members with the Strike Committee representing shipyard workers in the evening and on the night of 24/25 January 1971 at the Szczecin Shipyard.

Due to his competence and many years of experience in researching the crisis of 1970/1971 in Szczecin, Paziewski was certainly the most suitable author to prepare a critical edition of this unique source. The uniqueness of the presented historical record lies in the fact that this is the only known primary source of this kind not only in Poland, but also in the entire Eastern Bloc. For there has never been a similar meeting of the most important people in the party and the state with protesting workers on the premises of an industrial plant.

The fact that the protocols from this meeting were already published once in 1971 at the Literary Institute (Polish Instytut Literacki) in Paris does not change much here ${ }^{24}$. Firstly, this publication is difficult to access today - not every large academic library has it. Secondly, and much more importantly in my opinion, back then not everything was correctly interpreted, the text had a relatively large number of omissions and had not been edited in a critical manner. Only now has Paziewski managed to establish precisely who was speaking at a given time. What is more, he reached out to many of the participants of the meeting who were still alive, which allowed him to obtain a great deal of complementary information. As a result, we received a completely unique work, whose significance for the research on real socialism, not only in Poland, cannot be overestimated.

This review of the most important publications on December 1970 reveals a certain general picture and, consequently, a conclusion. It is quite evident that in recent years there has been an increase in the number of professional and impactful publications on the subject, but these are primarily photo albums and critical editions of documents, sometimes of great scholarly value. To this last category, one should add the collection of military documents edited by Edward J. Nalepa. These documents come from the Archives of the General Staff, the former Archives of the Pomeranian Military District and the former Secretariat of the Central Committee of the PZPR ${ }^{25}$.

In this situation, it is certainly a good thing that finally, 13 years after Michał Paziewski defended his doctoral dissertation titled December 1970 in Szczecin

${ }^{24}$ See Rewolta szczecińska i jej znaczenie, pp. 25-147.

${ }^{25}$ Grudzień 1970 w dokumentach wojskowych, opr. Edward J. NALEPA, Piotrków Trybunalski 2011. 
at the University of Szczecin, it appeared in print, in a version supplemented and extended by the latest findings of historiography ${ }^{26}$. It is undoubtedly one of the best and most valuable books on December 1970 to date. The author used a huge collection of primary sources, which he patiently gathered over many years, and proved his sophisticated skills in terms of historical research and analysis. The study by Piotr Brzeziński, Robert Chrzanowski and Tomasz Słomczyński, which is advertised on the book cover as 'the first book on the victims of December 1970 on the Gdańsk Coast' was also of innovative character, although obviously in another respect ${ }^{27}$. Apart from largely unknown iconographic material, the core of this book is constituted by biographical notes on 27 people killed in December 1970 on the streets of Gdańsk, Gdynia and Elbląg.

\section{WHO IS THE ADDRESSEE OF THIS TEXT?}

After reviewing the literature on the subject ${ }^{28}$, it is high time to attempt to find an answer to the question: who is the addressee of this text? Who was it written for? Of course, it is not the task of the author to decide who can read his text, let alone exclude anyone from the circle of potential readers, but in my opinion, it is primarily intended for English-speaking professional historians who study not only the history of the communist Poland, but also, more broadly, the history of Central and Eastern Europe and the communist system established by the Soviet Union in that territory in the aftermath of the Second World War.

It is also difficult to answer the question whose state of knowledge about December 1970 I am trying to present in this text? Before providing an answer, I must remind the reader of the truism that the level of knowledge on a given topic is different among different social groups. Obviously, the knowledge of experts on December 1970 is significantly broader and deeper than in the case of researchers dealing with other aspects of the history of communist Poland (e.g. the Stalinist Era or the 1980s). Furthermore, the level of such knowledge is even more differentiated among scholars studying earlier historical periods, and among people interested in history in a non-academic way or as a hobby, including teachers, university students and the most talented high schoolers. The so-called 'average Poles' obviously know even less about the history of

${ }^{26}$ Michał Paziewski, Grudzień 1970 w Szczecinie, Szczecin 2013.

${ }^{27}$ Piotr Brzeziński, Robert Chrzanowski, Tomasz SŁomczyński, Pogrzebani noca. Ofiary Grudnia '70 na Wybrzeżu Gdańskim. Wspomnienia, dokumenty, Gdańsk 2015.

${ }^{28}$ I discuss the literature on the subject in more detail in the second revised and extended edition of the monograph, see Jerzy EISLER, Grudzien 1970. Geneza, przebieg, konsekwencje, Warszawa 2012. 
December 1970. Thus, when the question about what is still unknown about December 1970 is asked, one first thinks of what researchers do not know about it, what aspects, threads and strands of events of that time still remain undiscovered.

I have already mentioned that one of the most serious problems faced by researchers when they start analysing the 'Polish months', including December 1970, is the question of how to name everything that happened in Poland in a reasonably precise and adequate manner. We must constantly remember that regardless of the greater or lesser similarities, the 'Polish months' were also very different from each other in terms of character, scale, form, complexity, involvement of the Soviet Union, and last but not least, short- and long-term consequences. It was also not uncommon for different, sometimes even contradictory or mutually exclusive threads, strands and aspects of these events to be covered by one and the same term. What, in fact, did the great social protest of December 1970 have in common with the parallel internal political game among the leaders of the Polish United Workers' Party, which resembled coup d'etat in the Central Committee, and which led to a shift in power in Poland in a matter of few days?

However, even if one considers only the aspect of social discontent, one can easily see significant differences between the 'Polish months', which must not be underestimated. What happened in June 1956 in Poznań and December 1970 in Gdańsk, Gdynia, Elbląg and Szczecin, when the authorities deployed thousands of soldiers equipped with hundreds of tanks and armoured carriers to suppress social protests in the streets, each time firing tens of thousands of shells of various types, causing the deaths of several dozen people, was something completely different from the events of March 1968 and June 1976, when only unarmed militiamen, with the exception of officers, were used to disperse street demonstrations.

\section{FINAL REMARKS - INTERNATIONAL DIMENSION}

Finally, one more general comment of an international nature. In 1970, which by no means can be an excuse for the cabinet of Gomułka, gruesome as it may sound now, one might say that shooting at citizens was not, unfortunately, something completely exceptional, and the December tragedy on the Polish Baltic coast, if it were assessed in an objective and factual manner, can be compared to similar military operations in other countries. It must not be forgotten that in the 1960s and 1970s, in the highly developed democratic countries of the West, too, the police and the army repeatedly used firearms to suppress street demonstrations, which usually resulted in fatalities. In order to prove this point, let us recall the Paris massacre of 1961, the Kent State shootings of 1970, and the Bloody Sunday of 1972 in Northern Ireland. 
It should also be made clear that over the past 50 years since the December tragedy, historians have managed to establish a great number of facts. We already know the answers to many of the most important questions, which, however, not always proved to be satisfactory for judges and prosecutors during the trial of party members, state dignitaries and senior military commanders, which took place in the course of several years. It seems that the archives in Poland, which have been widely accessible to researchers for 20 years, do not hold any more new historical records. Nonetheless, such valuable discoveries might be expected when historians gain unlimited access to the post-Soviet archives that today are located mainly in the Russian Federation. At the moment, however, this does not seem likely to happen in any foreseeable future.

Translated by Tomasz Leszczuk

\section{BIBLIOGRAPHY}

Balbus, Tomasz and Łukasz Kamiński. Grudzień '70 poza Wybrzeżem w dokumentach aparatu władzy. Wrocław: IPN, 2000.

Błaszak, Tomasz, Magdalena Dźwigała and Tomasz Kenar, eds. Szczeciński Grudzień '70 w dokumentach Służby Bezpieczeństwa. Szczecin: IPN, 2010.

Branach, Zbigniew. Grudniowe wdowy czekaja. Wrocław: Wydawnictwo Europa, 1990.

Brzeziński, Piotr, Robert Chrzanowski and Anna Nadarzyńska-Piszczewiat. Zbrodnia bez kary. Grudzień 1970 w Gdyni. Przebieg wydarzeń, represje, walka o prawdę. Gdynia: Oficyna Wydawnicza Verbi Causa, 2010.

Brzeziński, Piotr, Robert Chrzanowski and Tomasz Słomczyński. Pogrzebani noca. Ofiary Grudnia '70 na Wybrzeżu Gdańskim. Wspomnienia, dokumenty. Gdańsk: Polska Press, 2015.

Cenckiewicz, Sławomir. Gdański Grudzień '70. Rekonstrukcja - dokumentacja - walka z pamięcia. Gdańsk, Warszawa: IPN, 2009.

Chalimoniuk, Krzysztof. “Bibliografia Grudnia '70.” Rocznik Gdyński 22 (2010): 85-115.

Danowska, Bogumiła. Grudzień 1970 na Wybrzeżu Gdańskim. Przyczyny - przebieg reperkusje. Pelplin: Wydawnictwo Diecezji Pelplińskiej „Bernardinum”, 2000.

Domański, Paweł, ed. Tajne dokumenty Biura Politycznego. Grudzień 1970. Londyn: Wydawnictwo Aneks, 1991.

Eisler, Jerzy and Stanisław Trepczyński. Grudzień '70 wewnątrz 'Białego Domu'. Warszawa: A.W. Colibri, 1991.

Eisler, Jerzy, ed. Grudzień 1970 w dokumentach MSW. Warszawa: Wydawnictwo Bellona, 2000.

Eisler, Jerzy. Grudzień 1970. Geneza, przebieg, konsekwencje. Warszawa: IPN, 2012.

Eisler, Jerzy. Polski rok 1968. Warszawa: IPN, 2006.

Eisler, Jerzy. The 'Polish Months': Communist-Ruled Poland in Crisis. Translated by Jerzy Giebułtowski. Warsaw: The Institute of National Remembrance, 2019.

Głowacki, Andrzej. Kryzys polityczny 1970 roku. Warszawa: Instytut Wydawniczy Związków Zawodowych, 1990. 
Górski, Tadeusz and Henryk Kula. Gdańsk - Gdynia - Elblag '70. Wydarzenia grudniowe w świetle dokumentów urzędowych. Gdynia: Wydawnictwo „Inicjatywa”, 1990.

Grudzień 1970. Paryż: Editions Spotkania, 1986.

Korybutowicz, Zygmunt [Friszke, Andrzej]. Grudzień 1970. Paryż: Instytut Literacki, 1983.

Kostikow, Piotr and Bohdan Roliński. Widziane z Kremla. Moskwa-Warszawa. Gra o Polskę. Warszawa: Polska Oficyna Wydawnicza „BGW”, 1992.

Kowalewski, Maciej, Eryk Krasucki and Paweł Miedziński, eds. Historia, miasto, pamięć. Grudzień '70 - styczeń '71 (perspektywa szczecińska). Szczecin: IPN, 2010.

Krasucki, Eryk. Szczecińskie społeczeństwo i władza w styczniu i lutym 1971 r. Obraz źródłowy. Szczecin: IPN, 2010.

Kula, Henryk M. Dwa oblicza Grudnia '70. Oficjalne - rzeczywiste. Gdańsk: Wydawnictwo DJ, 2000.

Kwiatkowska, Wiesława and Izabella Greczanik-Filipp. Sa wśród nas. Gdynia: Społeczny Komitet Budowy Pomników Ofiar Grudnia w Gdyni, 2000.

Kwiatkowska, Wiesława. Grudniowa apokalipsa. Gdynia: Urząd Miasta Gdyni, 1993.

Kwiatkowska, Wiesława. “Grudzień 1970 w Elblągu.” In Elblag w grudniu 1970 roku, edited by Janusz Hochleitner, 33-46. Elbląg: Fundacja Elbląg, 2006.

Ligarski, Sebastian, ed. 'Intelektualiści polscy milczą zupetnie'. Grudzień 1970 - styczeń 1971 w Szczecinie. Szczecin: IPN, 2010.

Machałek, Małgorzata and Paweł Miedziński. Zbuntowane miasto. Szczeciński Grudzień '70 - Styczeń '71. Szczecin: IPN, 2007.

Nalepa, Edward J. Wojsko Polskie w grudniu 1970. Warszawa: Wydawnictwo Bellona, 1990.

Nalepa, Edward J., ed. Grudzień 1970 w dokumentach wojskowych. Piotrków Trybunalski: Naukowe Wydawnictwo Piotrkowskie, 2011.

Paziewski, Michał. Debata robotników z Gierkiem. Szczecin 1971. Warszawa: Biblioteka „Więzi”, Stowarzyszenie „Archiwum Solidarności”, 2010.

Paziewski, Michał. Grudzień 1970 w Szczecinie. Szczecin: IPN, 2013.

Piecuch, Henryk. Rozstrzelany grudzień. Warszawa: Wydawnictwo Story, 1990.

Rakowski, Mieczysław F. Przesilenie grudniowe. Przyczynek do dziejów najnowszych. Warszawa: Państwowy Instytut Wydawniczy, 1981.

Seidler, Barbara. Kto kazał strzelać. Grudzień '70. Warszawa: Polska Oficyna Wydawnicza „BGW”, 1991.

Sokołowska, Małgorzata, ed. To nie na darmo... Grudzień '70 w Gdańsku i Gdyni. Pelplin: Wydawnictwo Diecezji Pelplińskiej „Bernardinum”, 2006.

Szejnert, Małgorzata and Tomasz Zalewski. Szczecin. Grudzień - sierpień - grudzień. Londyn: Wydawnictwo Aneks, 1986.

Tarniewski, Marek [Karpiński, Jakub]. Płonie komitet (grudzień 1970 - czerwiec 1976). Paryż: Instytut Literacki, 1982.

Volobuyev, Vadim V. Pol'sha - 1970: Repetitsiya 'Solidarnosti'. Moskva, Sankt-Peterburg: Izdatel'stvo „Nestor-Istoriya”, 2012.

Wacowska, Ewa, ed. Poznań 1956 - grudzień 1970. Paryż: Instytut Literacki, 1971.

Wacowska, Ewa, ed. Rewolta szczecińska i jej znaczenie. Paryż: Instytut Literacki, 1971. 